\title{
HUBUNGAN PENGETAHUAN REMAJA PUTRI TENTANG KESEHATAN REPRODUKSI DENGAN KECEMASAN DALAM MENGHADAPI PREMENSTRUASI SYNDROME
}

\section{SRI WULAN ${ }^{1}$, BASYARIAH LUBIS ${ }^{2}$, NOVITA BR GINTING MUTHE ${ }^{3}$, ISKANDAR MARKUS SEMBIRING ${ }^{4}$, RAHMAD GURUSINGA ${ }^{5}$}

\author{
Institut Kesehatan MEDISTRA Lubuk Pakam \\ Jl. Sudirman No 38 Lubuk Pakam Kab.Deli Serdang, Sumatera Utara. \\ e-mail : wulan194@gmail.com \\ DOI : https://doi.org/10.35451/jkg.v4i1.847
}

\begin{abstract}
Premenstrual syndrome is a group of symptoms that occur in the luteal phase of the menstrual cycle that cause disruption to a person's work and lifestyle. Premenstrual syndrome makes women unable to function normally and requires treatment. This situation causes a decrease in the quality of life of women, for example students who experience premenstrual syndrome cannot concentrate on learning and their motivation to learn decreases because of the pain they feel. The purpose of this study was to determine the relationship between knowledge of young women and anxiety when facing premenstrual syndrome. This type of research is analytic by using a cross-sectional design. The population in this study were all female students in grades VII and VIII at SMP Negeri 1 Merbau in the 2020-2021 school year with a total population of 147 students and the sample in this study was 67 students who were taken by simple random sampling technique. Data analysis with chi-square test. The results of the analysis show that there is a relationship between knowledge about reproductive health and anxiety in dealing with premenstrual syndrome with a $p$ value of 0.000. It is recommended for health services to be able to hold counseling about premenstrual syndrome to increase the knowledge of young women about premenstrual syndrome.
\end{abstract}


Keywords : Knowledge, Anxiety, Young Women, premenstrual syndrome.

\section{PENDAHUlUAN}

Masa remaja merupakan masa peralihan dari kanak-kanak menuju ke dewasa yang dapat menyebabkan banyak perubahan seperti perubahan psikologis, biologis dan sosial budaya. World Health Organization (WHO) mendefenisikan remaja sebagai perkembangan dari saat timbulnya tanda-tanda seks sekunder sampai tercapainya maturase seksual reproduksi, peralihan dari ketergantungan sosial ekonomi menjadi mandiri, dan suatu proses pencapaian mental dan identitas dewasa. Ketika seorang remaja mengalami pubertas hal ini dianggap sebagai indikator awal masa remaja tetapi apabila tidak ada tanda secara biologis maka dinyatakan sudah berakhir masa remaja. Pada remaja putri akan mengalami perubahan yang sangat penting yaitu perubahan secara fisik ataupun psikologis (Nancy, 2012).

perubahan fisik yang dimaksud adalah proses kematangan yang terjadi pada organ reproduksi remaja putri yang ditandai dengan adanya mentruasi, pada saat remaja putri mengalami mentruasi maka akan mengeluarkan darah dari dalam Rahim bila sel telur tidak dibuahi dan pada umumnya mentruasi akan terjadi setiap bulanya (Nigrum.P.N, 2020).

Wanita yang menstruasi akan mengalami beberapa perubahan gejala fisik antara lain nyeri pada payudara, sakit kepala, jerawat, nyeri pinggul bahkan sampe odema dan juga akan mengalami perubahan emosional seperti perubahan mood, penurunan fungsi sosial, penurunan konsentrasi bahkan sampai depresi dan kecemasan hal ini dapat terjadi pada hari ke 7-10 sebelum mentruasi dan akan mereda pada saat menstruasi dimulai. Namun ada juga beberapa wanita yang mengalami gejala berkelanjutan hingga sampai hari ke 24-48 jam pertama pada saat siklus menstruasi dan akan mereda setelah beberapa hari kedepanya, gejala-gejala tersebut dikenal dengan premenstrual syndrome (Nugroho, T., \& Utama, B.I, 2014)).

Premenstrual syndrome merupakan sekelompok gejala yang terjadi dalam fase luteal dari siklus haid yang menyebabkan gangguan pada pekerjaan dan gaya hidup seseorang (Agustina \& Husna, N. 2018)). Premenstrual syndrome membuat remaja putri tidak bisa beraktivitas secara normal dan memerlukan pengobatan. Keadaan tersebut menyebabkan menurunnya kualitas hidup, sebagai contoh siswi yang mengalami premenstrual syndrome tidak dapat berkonsentrasi dalam belajar dan motivasi belajar menurun karena nyeri yang dirasakan dan mereka merasa sangat cemas dengan kondisinya karena tidak mampu untuk melakukan aktivitas sehari-hari. premenstrual syndrome paling banyak 
dialami oleh remaja hingga $63,1 \%$ dan $75 \%$ yang mengeluhkan gejala syndrome

premenstruasi serta $30 \%$ diantaranya memerlukan pengobatan (Nurmiaty dkk, 2011).

\section{Gejala Premenstrual Syndrome} Selain nyeri yang dirasakan oleh remaja putri, kecemasan juga merupakan salah satu gejala utama dan dapat menyebabkan gangguan tidur seperti insomnia atau hiperinsomnia. Kecemasan juga merupakan salah satu keadaan yang ditandai dengan perasaan takut dan sering kali menyebabkan emosi yang tidak normal. Pada awal siklus menstruasi remaja akan lebih rentan untuk mengalami Premenstrual Syndrome, selain itu tingkat gangguan mood akan cenderung meningkat dengan adanya perubahan hormone (Hadah, L.P. \& Esitra. H, (2019).

Pada dasarnya, remaja putri harus memiliki pengetahuan seputar kesehatan khususnya tentang kesehatan reproduksi, hal ini bukan hanya untuk menjaga kesehatan dan fungsi organ tetapi juga merupakan informasi penting untuk menghindari hal-hal yang tidak dinginkan terkait dengan kesehatan reproduksinya (Soetjiningsih, 2018).

Remaja putri memerlukan informasi atau pendidikan tentang proses dan kesehatan selama menstruasi, terutama tentang penanganan
Premenstrual Syndrome, jika remaja putri tidak memiliki pengetahuan terkait

penanganan Premenstrual Syndrome maka hal ini dapat menyebabkan kesulitan pada remaja putri pada saat menghadapi menstruasi (Sarwono, 2012).

Hasil survey awal yang dilakukan kepada 10 remaja putri di SMP Negeri 1 Merbau Kabupaten Labura 7 diantaranya tidak mengetahui apa itu kesehatan reproduksi dan premenstrual syndrome. Mereka mengatakan jika nyeri pada saat menstruasi mereka melakukan kompres air hangat dibagian perut, membeli obat penghilang rasa nyeri dan sebagian remaja mengatakan dengan tidur untuk menghilangkan rasa nyeri. Mereka juga mengatakan setiap bulan ketika menghadapi menstruasi mereka cemas akan dirinya karena terkadang mereka tanpa sadar memiliki emosional yang tidak seperti biasanya. Cenderung bermalasmalasan, tidak ada mood untuk banyak berbicara pada orang lain dan lebih suka untuk berdiam diri bahkan tidak masuk sekolah dengan alasan mengalami nyeri haid atau premenstrual syndrome.

\section{METODE}

Penelitian yang dilakukan menggunakan pendekatan cross sectional yaitu menekankan pada observasi variable dalam satu kali pada satu waktu (Nursalam, 2015). Penelitian ini dilakukan di SMP Negeri 
1 Merbau Kecamatan Merbau Kabupaten

Labura. Sampel dalam penelitian ini adalah

siswi remaja putri sebanyak 67 orang yang diambil secara acak yaitu simple rondom sampling dan ditentukan berdasarkan kriteria inklusi dan eksklusi. Instruman dalam penelitian ini menggunakan kuisioner yang terdiri dari 2 bagian yaitu pengetahuan tentang kesehatan reproduksi dan kecemasan menghadapi premenstrual syndrome. Analisa data dengan menggunakan tabel distribusi frekuensi dan uji statistik Chi Square dengan tingkat kepercayaan 95\% $(a=0,05) \quad$ (Sugiyono, 2016).

\section{HASIL}

Tabel 1. Distribusi Frekuensi Responden Berdasarkan pengetahuan Remaja Putri

\begin{tabular}{llll}
\hline No & $\begin{array}{l}\text { Pengetahuan } \\
\text { Responden }\end{array}$ & $(\mathrm{f}) \quad(\%)$ \\
\end{tabular}

\begin{tabular}{llcc}
\hline 1. & Baik & 14 & 20,9 \\
\hline 2. & Cukup & 19 & 28,4 \\
\hline 3. & Kurang & 34 & 50,7 \\
\hline & Total & 67 & 100 \\
\hline & Berdasarkan & tabel & diketahui
\end{tabular}

Berdasarkan tabel 1 diketahui

bahwa responden yang berpengetahuan baik sebanyak 14 orang (20,9\%), pengetahuan cukup sebanyak 19 orang $(28,4 \%)$ dan pengetahuan kurang sebanyak 34 orang $(50,7 \%)$.

Tabel 2. Distribusi Frekuensi Responden Berdasarkan Kecemasan dalam mengahdapi premenstrual syndrome pada Remaja Putri

\section{No Kecemasan \\ (f) \\ (\%) \\ Responden}

\begin{tabular}{llll}
\hline 1. & Ringan & 17 & 25,4 \\
\hline 2. & Sedang & 15 & 22,4 \\
\hline 3. & Berat & 35 & 52,2 \\
\hline & Total & 67 & 100 \\
\hline
\end{tabular}

Berdasarkan tabel 2 diketahui bahwa responden yang tingkat kecemasan ringan sebanyak 17 orang $(25,4 \%)$, tingkat kecemasan sedang sebanyak 15 orang $(22,4 \%)$ dan tingkat kecemasan berat sebanyak 35 orang $(52,2 \%)$.

Tabel 3. Tabulasi Silang Hubungan

Pengetahuan Remaja Putri Tentang

Kesehatan Reproduksi Dengan Kecemasan Dalam Menghadapi Premenstruasi Syndrome

\begin{tabular}{l|c|c|c|c|c|c|c|c|c|}
\hline \multirow{2}{*}{$\begin{array}{l}\text { Penget } \\
\text { ahuan }\end{array}$} & \multicolumn{7}{|c|}{ Tingkat Kecemasan } & \multirow{2}{*}{ p value } \\
\cline { 2 - 10 } & Ringan & \multicolumn{2}{|c|}{ Sedang } & \multicolumn{2}{|c|}{ Berat } & \multicolumn{2}{c|}{ Total } & \\
\hline & $\mathbf{n}$ & $\%$ & $\mathbf{n}$ & $\%$ & $\mathbf{n}$ & $\%$ & $\mathbf{n}$ & $\%$ & \\
\hline Baik & 11 & 64,7 & 2 & 13,3 & 1 & 2,8 & 14 & 20,9 & \multirow{2}{*}{0,00} \\
\hline Cukup & 5 & 29,4 & 11 & 73,4 & 3 & 8,5 & 19 & 28,3 & \\
\hline Kurang & 1 & 5,9 & 2 & 13,3 & 31 & 88,5 & 34 & 50,8 & \\
\hline Total & 17 & 25,4 & 15 & 22,4 & 35 & 52,2 & 67 & 100,0 & \\
\hline
\end{tabular}

Berdasarkan tabel 3 diketahui bahwa responden yang berpengetahuan baik dengan tingkat kecemasan ringan sebanyak 11 orang $(64,7 \%)$, sedang sebanyak 2 orang $(13,3 \%)$ dan berat 1 orang $(2,8 \%)$, responden yang berpengetahuan cukup dengan tingkat kecemasan ringan sebanyak 5 orang $(29,4 \%)$, sedang sebanyak 11 orang $(73,4)$ dan berat 3 orang $(8,5 \%)$, sedangkan yang berpengetahuan kurang dengan tingkat kecemasan ringan 1 orang (5,9\%), sedang 2 orang $(13,3 \%)$ dan berat sebanyak 31 orang $(88,5 \%)$. 


\section{menghadapi premenstrual syndrome}

Berdasarkan tabel 2 diketahui bahwa

\section{PEMBAHASAN}

a. Berdasarkan Pengetahuan Responden tentang Kesehatan Reproduksi

Dari hasil penelitian diketahui bahwa tingkat pengetahuan responden mayoritas berpengetahuan kurang sebanyak 34 orang $(50,7 \%)$ dan minoritas berpengetahuan baik dengan jumlah 14 orang (20,9\%).

Menurut Notoatmodjo. S (2010) pengetahuan merupakan hasil tahu dan ini bisa terjadi setelah seseorang melakukan penginderaan terhadap objek tertentu. Pada penelitian ini pengetahuan dibagi menjadi 3 kategorik yaitu baik, cukup dan kurang, peneliti menemukan mayoritas berpengetahuan kurang tentang kesehatan reproduksi.

Hal ini sejalan dengan penelitian Gasril.P.,Devita.Y \& Putri.E.E (2019). dari hasil penelitian diperoleh bahwa gambaran pengetahuan remaja putri tetang premenstruasi syndrome di SMP Negeri 29 Pekanbaru dari 99 responden mayoritas berpengetahuan sedang sebanyak 195,65\% dan berpengetahuan rendah sebanyak 78,26\%. Hal ini dikarenakan masa remaja merupakan masa pertumbuhan dan masa perkembangan sehingga mempunyai pengaruh pada pengetahuanya, seseorang memperoleh pengetahuan karena ada hubungan dengan orang lain atau karena adanya proses belejar.

b. Berdasarkan Tingkat Kecemasan dalam responden yang tingkat kecemasan ringan

sebanyak 17 orang $(25,4 \%)$, tingkat kecemasan sedang sebanyak 15 orang $(22,4 \%)$ dan tingkat kecemasan berat sebanyak 35 orang $(52,2 \%)$.

Menurut Notoatmodjo. S (2010) kecemasan terjadi karena faktor-faktor yang mempengaruhinya salah satu adalah pengetahuan dan pengalamannya, pengetahuan juga dipengaruhi oleh beberapa faktor salah satunya adalah sumber informasi dan usia.

Hal ini sesuai dengan penelitian Napitupulu. S. E.K (2019) hasil analisis menunjukkan ada hubungan antara tingkat kecemasan dan gejala fisik $\mathrm{Hal}$ ini kemungkinan karena didapatkan setiap individu memiliki setidaknya satu gejala pramenstruasi yang dibarengi dengan kecemasan. Premenstrual Syndrome merupakan kondisi medis umum yang mempengaruhi hubungan interpersonal wanita. Berbagai gejala emosional dialami wanita saat pra-haid, sehingga timbul kecemasan.

c. Hubungan Pengetahuan Remaja Putri Tentang Kesehatan Reproduksi Dengan Kecemasan Dalam Menghadapi Premenstruasi Syndrome.

Dari hasil penelitian diketahui

bahwa responden mayoritas berpengetahuan cukup dengan tingkat kecemasan ringan 
sebanyak 5 orang $(29,4 \%)$ dan minoritas berpengetahuan baik dengan tingkat

kecemasan ringan sebanyak 11 orang $(64,7 \%)$.

Menurut Stuart, G.W. (2013). kecemasan yang terjadi pada seseorang tidak sama, karena sebagian orang mengalami kecemasan karena dipengaruhi faktor ancaman terhadap integritas diri, perasaan takut terhadap sesuatu yang terjadi pada dirinya. Penyebab pasti munculnya kecemasan dalam menghadapi premenstrual syndrome diantaranya adalah fakor hormonal pada tubuh wanita yaitu ketidak seimbangan antara hormone estrogen dan progesterone. Kecemasan yang tidak diatasi segera akan dapat menimbulkan berbagi respon kecemasan, antara lain gelisah, keringat dingin, takut dan berbagai gangguan kesehatan yang dapat mengganggu aktivitas sehari-hari.

Berdasarkan hasil tersebut dapat disimpulkan sebagian besar responden berpengetahuan kurang mengalami kecemasan berat, sedangkan responden yang berpengetahuan baik dan cukup akan mengalami kecemasan sedang dan ringan. $\mathrm{Hal}$ ini bisa disebabkan karena sebagian besar responden masih berusia remaja pertengahan dan belum mendapatlan informasi tentang premenstrual syndrome sehingga kurangnya pengetahuan yang

didapatkan responden mengakibatkan responden kurang menegetahui tentang gejala-gejala yang dirasakan sebelum menstruasi dan itu menyebabkan responden

merasa khawatir sehingga responden mengalami kecemasan yang berat ketika menghadapi premenstrual syndrome (Ningrum.P.N, 2020).

Kurangnya pengetauan ataupun pengalaman dan juga kurangnya informasi yang dimiliki oleh remaja putri tentang premenstrual syndrome dapat memperberat gejala-gejala yang timbul, terkadang remaja putri mencoba mengatasi gejala-gejala premenstrual syndrome dan bersifat cobacoba tanpa adanya pengetahuan yang cukup dan benar. Semakin baik pengetahuan tentang kesehatan reproduksi maka semakin positif pula remaja putri dalam menghadapi premenstrual syndrome.

\section{KESIMPULAN}

Hasil penelitian menunjukkan bahwa ada hubungan antara pengetahuan tentang kesehatan reproduksi dengan kecemasan dalam menghadapi sindrom pramenstruasi dengan $p$ value 0,000. Disarankan kepada pelayanan kesehatan untuk dapat mengadakan penyuluhan tentang premenstrual syndrome untuk meningkatkan pengetahuan dan menurunkan tingkat kecemasan remaja. 


\section{DAFTAR PUSTAKA}

Agustina \& Husna, N. (2018). Determinan Premenstruasi Syndrome Pada Siswi SMAN 1 Unggul Darul Imarah Lampeunureut Aceh Besar. Journal of Healthcare Technology and Medicine Vol. 4 No. 1

Gasril.P.,Devita.Y \& Putri.E.E (2019). Gambaran Pengetahuan Remaja Putri Tentang Premenstruasi Syndrome di SMP Negeri 29 Pekanbaru. Jurnal Photon Vol.9 No.2 Juni 2019.

Hadah, L.P. \& Esitra, H. (2019). Hubungan Premenstruasi Sindrom Dengan Tingkat Kecemasan Pada Siswi Kelas X SMA Muhammadiyah 3 Yogyakarta. Jurnal Bidang Ilmu Kesehatan. Vol. 9 No. 3

Nancy.(2012). Buku Ajar Tumbuh Kembang Anak dan Remaja EdisiPertama. Jakarta: Sagung Seto

Napitupulu. S. E.K (2019). Hubungan antara tingkat kecemasan dan sindroma pramenstruasi pada remaja putri. http://repository.trisakti.ac.id/usaktia na/index.php/home/detail/detail_kole ksi/7/SKR/th_terbit/00000000000000 095864/2015

Ningrum.P.N. (2020). Analisis Tigkat pengetahuan Remaja Tentang

Gejala Premenstruasi Sindrom

Dengan Aplikasi Kelender

Menstruasi. Jurnal Global Health Science Vol.5
No.1 March 2020.

Notoatmodjo, S. (2010). Promosi Kesehatan Teori dan Aplikasi. Jakarta: Rineka Cipta.

Nugroho, T., \& Utama, B.I. (2014) Masalah Kesehatan Reproduksi Wanita. Yogyakarta : Nuha Medika

Nurmiaty, Wilopo, SA.,\& SUdargo T. (2011). Perilaku dengan Kejadian Sindome Premenstruasi pada Remaja. Berkala Kedokteran Masyarakat. Vol.27, no.2, hlm., 75-82.

Nursalam. (2015). Metodologi Penelitian Ilmu Keperawatan (Edisi 4). Jakarta: Salemba Medika.

Sarwono (2012). Psikologi Remaja. Jakarta : Rasa Grafindo Persada.

Soetjiningsih. (2018). Buku Ajar Tumbuh Kembang Remaja dan Permasalahannya edisi kedua. Jakarta : Sagung Seto

Stuart, G.W. (2013). Buku Saku Keperawatan Jiwa. Ahli bahasa: Ramona P. Kapoh \& Egi Komara Yudha. Jakarta: EGC

Sugiyono. (2016). Metode Penelitian Pendidikan (Pendekatan Kuantitatif, Kualitatif, dan R\&D). Bandung: Alfabeta 